\title{
Article \\ Subjective Knowledge, Perceived Risk, and Information Search when Purchasing a Franchise: A Comparative Exploration from Australia
}

\author{
Peter Balsarini *(D), Claire Lambert (D), Maria M. Ryan (D) and Martin MacCarthy (D) \\ School of Business and Law, Edith Cowan University, Joondalup, WA 6027, Australia; \\ c.lambert@ecu.edu.au (C.L.); m.ryan@ecu.edu.au (M.M.R.); m.maccarthy@ecu.edu.au (M.M.) \\ * Correspondence: p.balsarini@ecu.edu.au
}

check for

updates

Citation: Balsarini, Peter, Claire Lambert, Maria M. Ryan, and Martin MacCarthy. 2021. Subjective Knowledge, Perceived Risk, and Information Search when Purchasing a Franchise: A Comparative Exploration from Australia. Journal of Risk and Financial Management 14: 338

https://doi.org/10.3390/jrfm14080338

Academic Editor: Elena Horska

Received: 18 May 2021

Accepted: 11 July 2021

Published: 21 July 2021

Publisher's Note: MDPI stays neutral with regard to jurisdictional claims in published maps and institutional affiliations.

Copyright: (C) 2021 by the authors. Licensee MDPI, Basel, Switzerland. This article is an open access article distributed under the terms and conditions of the Creative Commons Attribution (CC BY) license (https:// creativecommons.org/licenses/by/ $4.0 /)$.
Abstract: Franchising has long been a method by which organizations seek to expand and facilitate local market development. However, franchising as a growth strategy can often be hampered by lack of suitable franchisees. To mitigate this shortage, some franchisors have engaged in recruiting franchisees internally from the ranks of their employees in addition to the traditional approach of recruiting franchisees externally. Predominantly franchisees are individuals rather than corporations and thus purchasing a franchise should most commonly be characterized as a consumer acquisition. To explore the relationship between subjective knowledge, perceived risk, and information search behaviors when purchasing a franchise qualitative interviews were conducted with franchisees from the restaurant industry. Half of these respondents were externally recruited having never worked for the franchisor and half were internally recruited having previously been employees of the franchisor. The external recruits expressed a strong desire to own their own business and engaged in extensive decision-making processes with significant information search when purchasing their franchises. Contrastingly, the internal recruits expressed a strong desire to be their own boss and engaged in limited, bordering on habitual decision-making processes with negligible information search when acquiring their franchises. The results reveal that differences in subjective knowledge and perceived risk appear to significantly impact the extent of information search between these two groups. A model of the relationship between subjective knowledge, perceived risk and information search in the purchasing of a franchise is developed that reconciles these findings. The findings also have practical implications for franchisors' franchisee recruiting efforts which are integral to their capacity to develop local markets.

Keywords: consumer behavior; local market development; franchising; subjective knowledge; perceived risk; information search; franchising

\section{Introduction}

Franchising has long represented a strong strategic growth option for organizations seeking to expand into diverse markets. During previous periods of economic recovery franchising has led the way by rebounding more rapidly than other business sectors (Frandata 2021). Indeed, currently the US International Franchise Association is projecting franchising to bounce back strongly in 2021 by adding 26,000 franchise locations [3.5\% above 2020], 800,000 jobs [10\% above 2020] and over USD 477 billion to GDP [7\% above 2020] (Frandata 2021). Franchising is especially prominent in the retail sector where it accounts for between $30 \%$ and 50\% of the retail sales in Germany, the USA and Australia and a lesser but extremely fast-growing percentage of retail sales in many developing economies (Dant et al. 2011).

Business format franchising which involves the provision of a full business system is the preeminent form of franchising (Storholm and Scheuing 1994) and, as in the bulk of the literature, is the focus of this research. The resource scarcity view of franchising 
posits that in order to expand their organizations franchisors need to gain access to the scarce resources of financial capital and entrepreneurial capacity provided by franchisees (Oxenfeldt and Kelly 1969; Norton 1988b). In his seminal work, Bradach (1995) postulated four strategic imperatives for franchise system success two of which, local responsiveness and system-wide adaption directly confer advantages on franchise organizations' capacity to facilitate local market development when compared with non-franchised organizations. Local responsiveness represents the capacity to understand customer needs and requires the flexibility to adapt to local market conditions. It is the individual franchisee's close proximity to customers that generates the local market knowledge (Boulay et al. 2016) which creates opportunities for them to adapt and innovate (Croonen et al. 2016; Bürkle and Posselt 2008). This ultimately provides franchised organizations with a competitive advantage when seeking to develop diverse local markets (Minkler 1992). Furthermore, the agency theory view of franchising suggests that as franchisees are entitled to a share of unit profits (Rubin 1978) this provides them with a much stronger incentive to attend to and respond to local market needs than would occur with employee managers of equivalent company-owned units. Where local innovations end up having broader application this penchant for optimizing local responsiveness synergistically feeds into the system-wide adaption imperative (Darr et al. 1995). Indeed, franchisees through their local adaption efforts alter current offerings, create novel solutions to problems, and innovate new market offerings that may then spread through the entire organization (Kaufmann and Eroglu 1999). There are a number of famous examples where innovations motivated by franchisees local responsiveness became critical to the ongoing success of franchise systems (Dada et al. 2015; Meiseberg 2013; Watson et al. 2016). For example, the world's pre-eminent franchisor McDonald's has credited franchisees with the creation of numerous leading products including the iconic Big Mac, Filet-O-Fish, Egg McMuffin, Hot Apple Pie and McFlurry Dessert (Kroc and Anderson 1977; McDonald's n.d.).

The potential benefits derived by franchise systems from franchisees are reliant on access to an ongoing pool of new franchisees. However, research has consistently found that lack of available new franchisees remains franchisors' number one growth challenge (Bradach 1997; Frazer et al. 2012; Frazer et al. 2014). Franchisors who better understand the franchise acquisition process should be better placed to successfully recruit franchisees. Yet, despite the critical importance of better comprehending the purchase processes of franchisees, to date there have been few investigations into their franchise acquisition decision processes. Certainly, there are no studies that explore the relationship between the key consumer behavior constructs of subjective knowledge, perceived risk, and information search when purchasing a franchise. Furthermore, just as the insights that accrue to marketers who segment and then target various consumer categories are well established, such segmentation is also important for franchisors seeking to expand by targeting various categories of franchisees. One ramification of the franchisee shortage has been further franchisee segmentation involving the identification of the two nascent categories of franchisees that provide the contexts for this research. Firstly, externally recruited franchisees (ERFs) who comprise franchisees recruited from outside the franchisor organization and secondly internally recruited franchisees (IRFs) who constitute franchisees recruited from within the franchisor organization having been employees of the franchisor (Balsarini et al. 2020). The prevalence of IRFs is estimated at 40\% (Bradach 1997; Lashley and Morrison 2000), yet a paucity of research on IRFs has meant they have been predominantly ignored by the literature. By gaining greater insight into the subjective knowledge, perceived risk, and information search behaviors undertaken by IRFs and ERFs when purchasing their franchises, franchisors will be better placed to formulate and implement strategies that overcome the franchisee shortage which is currently hindering market development.

Accordingly, this research seeks to explore the following research questions: 
RQ1. What is the relationship between subjective knowledge, perceived risk, and information search behaviors when purchasing a franchise?

RQ2. Does this relationship vary between externally recruited franchisees and internally recruited franchisees when purchasing their franchises?

This paper is structured as follows. Section 2 reviews the literature related to the key topics of the paper. Section 3 describes the relevant conceptual framework. Section 4 reports the research method and sampling used. Section 5 presents the results. The discussion in Section 6 proposes a model to reconcile the results for ERFs and IRFs. Managerial, practical, and theoretical implications are also identified. Section 7 provides a conclusion.

\section{Literature Review}

\subsection{Franchisee as a Consumer}

In some circumstances the franchisor-franchisee relationship should be framed within a business-to-business context (B2B), such as where a corporation acquires the franchise rights for an entire country. However, Dant et al. (2013) contends that a B2B approach to franchising research "has truncated theory development" (p. 280) as most franchise transactions involve the acquisition of a franchise outlet by an individual (Grace and Weaven 2011; Kaufmann 1999). Agency theory has often been identified as a key explanation as to why franchisors choose to engage in franchising rather than operating all stores themselves, and why they franchise predominantly to individuals (Alchian and Demsetz 1972; Alon 2001; Eisenhardt 1989; Lafontaine 1992; Rubin 1978). The imputation being that as franchisees have a residual claim to their unit's profits this incentive fosters a mindset that improves results far beyond those of mere employee managers (Lafontaine and Kaufmann 1994; Norton 1988a; Perryman and Combs 2012). As this disposition can only take place in the mind of an individual (i.e., franchisee versus employee) the result is a preference for franchisors to franchise to individuals. Hence, to gain this Agency theory advantage it is a requirement of most major franchisors that franchisees be individuals rather than corporations, and that they expend full-time effort into their franchises (Kaufmann 1999). Consequently, consistent with Atwell (2015); Buchan (2009); Buchan (2013); Frazer et al. (2016a) and Spencer (2013) this research maintains the view that in acquiring a franchise, individual franchisees are appropriately categorized as consumers.

\subsection{Externally Recruited Franchisees and Internally Recruited Franchisees}

As the name suggests, externally recruited franchisees (ERFs) are defined as franchisees who have been recruited from outside the franchise system, never having been employees of the franchisor or one of its franchisees. Accordingly, they represent the prototypical conceptualization of a franchisee, being an individual seeking to go into business but lacking the required knowledge and skills in that area and thus seeking to alleviate this deficiency by purchasing a franchise (Norton 1988b). Hence the seminal description of owning a franchise as "being in business for yourself but not by yourself" (Kaufmann 1999, p. 345). The internal recruiting of franchisees has long been an active practice in the franchise industry as evident from numerous trade publications (Pillon 2019; Stowe 2015; Syed and Syed 2019; Taylor 2015). To date there has only been one academic study focused on IRFs, Balsarini et al. (2020) and it provides the following definition "an internally recruited franchisee is ... a franchisee who, prior to their franchise recruitment, was an employee of the franchisor or an employee of one of its franchisees" (p. 4). Most often IRFs are employees with at least 10 years of service to the franchise system (Kroc and Anderson 1977) and are proven operators possessing a strong knowledge base and performance history in managing an outlet (Bradach 1997). Despite the prevalence of IRFs in franchise systems being estimated at $40 \%$, with the balance of $60 \%$ being ERFs, only one prior study (Balsarini et al. 2020) has distinguish between IRFs and ERFs. Accordingly, these two categories of franchisees warrant further investigation in their own right and provide the contexts for this research. 


\subsection{The Franchise as a Strategic, Predominantly Intangible Purchase}

Decision making has long been a prevalent consumer research topic however, many studies have merely focused on simplistic, low involvement, frequent purchases with limited attention being directed at complex, high involvement, infrequent purchases that often entail higher risks and have greater long-term consequences (Martin et al. 2015). Bazerman (2001) also observed that consumer research has often "been silent regarding many of consumers' most important buying episodes" (p. 499). Gronhaug et al. (1987) termed these important consumer decisions as strategic purchases and described them as those having long term affects and involving significant commitment of resources. The majority of consumer strategic purchase enquiry has focused on the context of high value durable goods such as housing and vehicles (Koklic and Vida 2011; Punj and Brookes 2002; Savolainen 2009). However, other significant products, particularly those with more intangible characteristics such as franchises have yet to be examined through the consumer strategic purchase lens. While it is true a franchise can involve tangibles such as products and business premises, business format franchising mostly represents the franchisor's provision of the intangibles of the operating system, the brand, marketing, training, and location selection services (Bender 2015). With the median acquisition cost for a retail franchise approaching USD 225,000 (Frazer et al. 2016b), for those individuals buying a franchise it generally represents their second largest purchase after housing. Moreover, franchisees are not only required to invest significant financial capital to purchase a franchise but to also expend significant human capital as they are typically required to work full-time in the business rather than act as passive investors (Kaufmann 1999). Consequently, as over $50 \%$ of franchise outlets are owned by franchisees in spousal/partner type relationships (Frazer et al. 2010), buying a franchise represents not only a high involvement consumer purchase but often a lifechanging purchase for franchisees and their households. Over $85 \%$ of franchise contracts have terms of between 5 and 10 years (Frazer et al. 2010) so they also constitute enduring products with long-term ramifications. Hence, purchasing a franchise represents a mostly intangible, high value, high involvement, infrequent, syncretic consumer purchase with long-term, strategic ramifications.

\subsection{Information Search, Subjective Knowledge, and Perceived Risk}

Prior to the current research, the relationship between subjective knowledge, perceived risk and information search in the purchase of a franchise has remained unexplored. In deciding how to best fill their needs consumers often engage in information search behaviors seeking to supplement their existing subjective knowledge. The extent of information search activities undertaken by consumers often varies based on perceived risk and the specific characteristics of the category of the product sought (Wei and Lu 2013; Maity and Dass 2014). Previous research has viewed strategic purchases as involving complex, high involvement decisions that require significant information search (Erasmus et al. 2014; Gronhaug et al. 1987). While information represents "facts provided or learned about something or someone" (Oxford Dictionaries n.d.) information search is defined as "the effort aimed at acquiring information from the external environment" (Srinivasan and Ratchford 1991, p. 235). According to Utkarsh (2017) information search has key determinants that include the ability to search and the motivation to search. In deciding how to satisfy a need, consumers often seek to augment the subjective knowledge they perceive they already possess by undertaking external information search (Gibler and Nelson 2003; Punj 1987). Thus, the level of subjective knowledge and the extent of information search are frequently portrayed as being intrinsically linked. Indeed, the concept of consumer knowledge has long been deemed a key construct in consumer decision-making (McNeal and McDaniel 1981), particularly with regard to important decisions (Raju et al. 1995; Hadar et al. 2013; Oh and Abraham 2016). While objective knowledge is what the consumer knows about the product in actuality, subjective knowledge represents the level of knowledge a consumer perceives they possess (Brucks 1985; Hadar et al. 2013). As such subjective knowledge has been deemed the more critical construct in understanding consumers' information search 
behaviors and decision heuristics (Brucks 1985; Hadar et al. 2013; Park and Lessig 1981; Raju et al. 1995). Previous research has provided mixed results for the relationship between subjective knowledge and information search, with the product and the context seeming to play a pivotal role. One vein of enquiry found that higher subjective knowledge levels raised information search, ostensibly due to increased confidence in the ability to search (Utkarsh and Agarwal 2019). Conversely, an alternate vein of enquiry found elevated levels of subjective knowledge lowered information search due to decreased motivation to search as consumers who "believe they are already knowledgeable about a topic area will be less likely to search out additional information" (Radecki and Jaccard 1995, p. 114).

Risk represents another important construct when researching consumer purchase behaviors. Perceived risk being characterised as the subjective assessment made by consumers in relation to the risks inherent in deciding between options when endeavoring to satisfy a need (Conchar et al. 2004). Koklic (2011) postulated a model of perceived risk in the context of the purchase of a prefabricated house, a high value item, which has perceived risk as the central construct in the relationship between subjective knowledge, perceived benefits, and information search. Indeed, risk tends to be greater for high-priced products (Chaudhuri 2002), thus suggesting perceived risk when purchasing a franchise would be high. Dowling and Staelin (1994) postulated that perceived risk has an integral effect on consumers' risk handling behaviors in particular information search, with consumers continuing "to seek information until they are able to reduce their specific risk level below their acceptable risk" (p. 133). Thus, the level of perceived risk and the extent of information search in purchase undertakings are often highly correlated.

\section{Conceptual Framework}

In 1968 Engel, Kollat, and Blackwell developed a general model of the buyer decision process which has continued to be refined and ultimately morphed into the traditional five-step consumer decision process model prevalent in most consumer behavior textbooks (Ashman et al. 2015; Darley et al. 2010). The stage sequence being: need recognition/unmet need, information search, alternative evaluation, choice/purchase, and post-purchase evaluation. As Virdi et al. (2020) observes papers such as Lye et al. (2005); Karimi et al. (2015) and Karimi et al. (2018) suggest some stages of this traditional model are often skipped, and some consumer decision processes are more iterative than linear. Moreover, the generic nature of this five-step model has been criticized for its emphasis on rationality and its questionable predictive value, hence the trend towards more product and context specific models (Erasmus et al. 2001). Research on franchise buyer decision models is scant with only three published papers within the past 26 years. Two of those studies, Hing (1995) and Yeung et al. (2016) both used the Engel et al. (1978) model as their theoretical framework and thus are likely exposed to the criticisms levelled above. A further critique of Hing (1995) model of franchisee buyer behavior reveals it is primarily focused on satisfaction as a post-purchase outcome and provides only perfunctory attention to the processes leading to the actual franchise purchase decision itself. The Yeung et al. (2016) model also has constraints primarily due to its focus on the Chinese hospitality industry. Thus, the generalizability of this model to other franchise purchase contexts is restricted due to its strong emphasis on the role of 'Guanxi' the Chinese "system of social networks and influential relationships which facilitate business" (Oxford Dictionaries n.d.). With the deficiencies of general buyer behavior models, numerous scholars have suggested phased models of consumer decision processes to reduce complexity, particularly for complicated acquisitions (Koklic and Vida 2011; Nedungadi 1990; Shocker et al. 1991). The remaining study on franchise purchasing by Kaufmann (1999), formulated a phased model of the "decision to purchase a franchise within the broader context of the decision to become self-employed" (Kaufmann 1999, p. 345). Kaufmann (1999) Process Model provides the conceptual framework for this research and suggests that when deciding to purchase a franchise one first decides to pursue self-employment and then a business sector/industry decision is made. Subsequently, an organizational-type decision is made to choose either a 
franchise business or an independent business. At this point some may exit the franchise purchase process to pursue independent business opportunities. For those continuing the pursuit of a franchise, Kaufmann postulates a decision between franchise brands within the selected sector is then made, ultimately leading to a franchise purchase.

\section{Method}

Due to the paucity of studies on the franchise acquisition behaviors of ERFs and IRFs, an exploratory, inductive methodology was adopted for this research (Creswell 2014). The aim being to gain an understanding of the relationship between the constructs of subjective knowledge, perceived risk, and information search when purchasing a franchise, and to ascertain whether this relationship varies between ERFs and IRFs. Semi-structured interviews were conducted one-to-one exploring the participants' franchise purchase behaviors related to the three relevant constructs of subjective knowledge, perceived risk, and information search. For RQ1 the theoretical lens of Kaufmann's Process Model was employed to explore the franchise acquisition process. While this lens provided a framework for the topics pursued (Creswell 2014) an inductive mindset was maintained with no propositions developed in advance. The interviewees were merely questioned relating to why they purchased a franchise, what subjective knowledge they possessed, what risk they perceived and what information search behaviors, if any, they engaged in. Thus, the approach employed for RQ1 was more akin to thematic analysis than formal framework analysis. Likewise, for RQ2, as no previous studies have compared subjective knowledge, perceived risk, and information search between ERFs and IRFs the approach remained inductive. With both research questions, the objective was to let the resultant data be instrumental in theory development (Corbin 2017). The interviews began by capturing self-employment and career background information on each participant. This allowed for subsequent triangulation with more extensive detail provided by participants' profiles on social media platforms such as LinkedIn. The interviews were recorded and lasted up to 75 min, with interview notes made to capture contextual information (Saunders et al. 2009).

Since its original application in psychology, thematic analysis (Braun and Clarke 2006) has been applied to the analysis of qualitative research data in many disciplines and is now widespread in organizational research (Grace et al. 2016; King and Brooks 2018). In this research the six phases of thematic analysis: data familiarization, coding, generating initial themes, reviewing themes, theme defining and writing results were followed when identifying, organizing, and interpreting themes in the interview data. Data familiarization began with the researchers conducting the interviews, it continued during transcription which was also undertaken directly by the researchers (Frazer 2004). The transcripts were then read several times facilitating the researchers becoming intimately familiar with the content. Notes were made during each iteration. Coding then occurred, involving generating labels (codes) for data deemed relevant to the two research questions. From patterns in these codes initial themes were identified and developed (Attride-Stirling 2001). Review and discussion between the researchers then ensued surrounding these potential themes as to which represented "patterns of shared meaning underpinned or united by a core concept" (Braun and Clarke 2019, p. 593). Through collaboration intercoder consensus (MacPhail et al. 2016) was achieved pertaining to the themes' relevance to the research questions (Denzin and Lincoln 2005). Significant themes were then defined and named, with relationships and hierarchies between themes developed. An analytic narrative in response to each research question was developed and written up citing quotes that epitomize respondents' perspectives (Labuschagne 2003). Finally, as "qualitative data analysis is about telling 'stories', about interpreting and creating" (Braun and Clarke 2019, p. 591) a model was derived that synthesizes the findings. 


\section{Sampling}

To adequately explore the research questions participants who had undertaken a franchise purchase decision were enlisted for semi-structured interviews. To this end, a purposive sample of franchisees from the Australian restaurant industry was obtained. To facilitate this study's focus on the contrast between ERFs and IRFs, all participants were recruited from one restaurant system in one country, thus keeping the system and location as constants to limit extraneous variables. As per Guest et al. (2006), snowball sampling continued until sufficient code saturation was attained. This led to interviews being undertaken with 14 franchisees. Four of the 14 franchisees had previously owned businesses, while the other 10 had only ever been employees. Seven were externally recruited (ERFs), not having been employees of the franchisor prior to their franchise purchase. A further seven were internally recruited (IRFs) and were employees of the franchisor at the time of their franchise purchase. These seven IRF participants had a subjective knowledge repository accumulated over 89 years of combined employee experience with the franchisor, ranging from three to 20 years with the average being 12.7 years of service. Five of the seven IRFs had known no other employer, originally having started with the franchisor in their first jobs and then remaining to pursue corporate careers. Prior to purchasing a franchise all ERFs except one, had been actively pursuing other possible self-employment options, such as starting a new business from scratch, purchasing an independent business or purchasing a different franchise. Conversely, none of the IRFs had been actively pursuing other possible self-employment options. Characteristics of the sample are presented in Table 1.

Table 1. Participants' Characteristics.

\begin{tabular}{|c|c|c|c|c|}
\hline $\begin{array}{c}\text { Franchisee } \\
\text { IR Prefix-Internally } \\
\text { Recruited ER } \\
\text { Prefix-Externally Recruited }\end{array}$ & Recruited & $\begin{array}{c}\text { Previously } \\
\text { Self-Employed }\end{array}$ & $\begin{array}{l}\text { Prior to Purchasing a } \\
\text { Franchise, Years as } \\
\text { Employee of } \\
\text { Franchisor }\end{array}$ & $\begin{array}{c}\text { Prior to Purchasing a } \\
\text { Franchise Were Actively } \\
\text { Pursuing Other } \\
\text { Self-Employment Options }\end{array}$ \\
\hline IR1 & Internally * & Yes & 14 & No \\
\hline IR2 & Internally * & No & 10 & No \\
\hline IR3 & Internally * & No & 11 & No \\
\hline IR4 & Internally * & No & 17 & No \\
\hline IR5 & Internally * & No & 20 & No \\
\hline IR6 & Internally & No & 14 & No \\
\hline IR7 & Internally & No & 3 & No \\
\hline ER8 & Externally & Yes & 0 & Yes \\
\hline ER9 & Externally & Yes & 0 & Yes \\
\hline ER10 & Externally & No & 0 & Yes \\
\hline ER11 & Externally & No & 0 & Yes \\
\hline ER12 & Externally & No & 0 & Yes \\
\hline ER13 & Externally & No & $0^{\#}$ & No \\
\hline ER14 & Externally & Yes & $0^{\#}$ & Yes \\
\hline
\end{tabular}

\# both worked with a supplier to the franchisor prior to acquiring their franchises. * indicates the franchisor had been their only employer and they had never been employed by another entity prior to buying their franchises. [Note: while IR1 had previously been self-employed, they had never been employed by a separate entity other than the franchisor].

\section{Results}

\subsection{Differences in the Nature of The decision between ERFs and IRFs}

All ERFs followed the decision sequence foreshadowed in Kaufmann's Process Model and were on a quest to 'own their own business' either by deciding to continue to be, or become self-employed. Comments such as "I always had a desire to have my own business" (ER13) were consistent among ERFs. ERFs expressed various reasons for wanting to pursue their own business rather than being employed "I wanted to improve my financial situation" (ER10); "it was time to do something for myself" (ER11). All ERFs, except one who already owned a business and was approached directly by the franchisor, initiated the purchase 
process and were actively looking for self-employment opportunities-“I was looking around for business opportunities" (ER10). Two of the ERFs (ER9 and ER10) responded to the franchisor's advertisements seeking franchisees. Some ERFs then progressed from the organizational-type decision [franchise or independent business], to the sector decision, and then the brand decision. While for others, the sector decision preceded the organizationaltype decision. In pursuing this decision sequence, ERFs engaged in an extensive franchise purchase decision process.

IRFs' unmet need was 'to be their own boss' which contrasted markedly with ERFs who expressed a strong desire to 'own their own business'. The observation " $I$.. wanted to be my own boss" (IR5) encapsulated the IRF mindset. They did not follow the Kaufmann Process Model's decision sequence utilized by ERFs. For example, while most IRFs informed their franchisor employer that at some point in the future they would like to become a franchisee, they simply perceived this as an alternative career trajectory to trying to climb the corporate ladder. Consequently, this did not extend to a broader desire for self-employment beyond a franchise in the chain with which they were currently employed. Their specific discrete decision to become self-employed was absent. Instead, for IRFs the common catalyst seemed to be escaping the escalating demands of corporate life "they did offer me a couple of roles [promotions] but it would have been a lot of travel" (IR4); "we just had a child ... and I was travelling a lot with work" (IR5). Many IRFs had also worked closely with franchisees and coveted their self-efficacy "ultimately, I think it was a case of working with all the different franchisees" (IR4). IRFs had also seen former fellow employees that they considered peers become successful franchisees, which reinforced the option of becoming a franchisee as their next professional aspiration.

For IRFs, rather than seeing purchasing a franchise as a business acquisition decision, as ERFs did, it was viewed more as a career decision. For IRFs the key issue was, should they continue to try to progress up the corporate ladder with their franchisor employer or pursue the franchise route, still with this same franchisor. In either case continuity would be maintained, with the parties to the relationship (the employee/IRF and the employer/franchisor) essentially remaining the same, just the nature of the relationship would be altered. IRF, IR6 described the decision to purchase a franchise from their employer as "basically a fork in the road" and being heavily influenced by their limited prospects of promotion as an employee of the franchisor "I might not have been able to grow much more in the corporate world" (IR6). Hence, in IR6's case they decided to pursue a franchise when one was offered. Indeed, for IRFs the decision sequence was truncated as they progressed automatically straight to the end of the purchase decision sequence and simply pursued a franchise with the brand with whom they were incumbent as employees. Thus, their extremely limited decision-making sequence saw them bypassing and not considering alternative organizational-types, sectors, or brands. Significantly no IRFs were actively pursuing other potential self-employment options. Indeed, for two of the IRFs the catalyst for their franchise acquisition process was the franchisor approaching them to consider becoming franchisees. These two respondents had expressed no interest in a franchise or any other form of self-employment. "The restaurant I was running (as an employee) was in the top 20 (in the state) so they approached me (about a franchise). I did not approach them" (IR7). Similarly, IR6 had not even considered becoming a franchisee until they were approached internally by the franchisor "I did not even think I was interested ... (a colleague) came into my office one day and said, (restaurant $A$ ) and (restaurant B) are up for franchising if you are interested. And that was the very first time that I had even considered being a franchisee" (IR6). Overall, IRFs pursued a franchise in the chain where they were already employed as part of a quest to become their own boss. They perceived this choice as merely a change in the relationship status with their franchisor employer, from employee to franchisee, rather than a decision to be self-employed. Thus, when compared with ERFs, the IRFs' decision involved them engaging in a much more limited, almost habitual decision-making process. 


\subsection{The Influence of Being ERF or IRF on Information Search, Subjective Knowledge, and Perceived Risk}

ERFs engaged in far more information search than IRFs "I . . read a couple of articles in the newspaper about them (the franchisor)" (ER10); after reading a book about them "I actually thought ... that (they) would be a good business" (ER8). By way of example, respondent ER9 actively engaged in extensive information search "I spoke to business brokers and looked at a lot of rubbish". ER9 also investigated numerous franchises in different industries "I looked into a cleaning franchise ... and ... new car franchises". Like other ERFs, ER9 had formulated search criteria which included an industry they could enjoy, that provided them with a job, not requiring a business partner, in retail, with good margins, and good sales volume. To gain further information and thus augment their lack of subjective knowledge, all ERFs engaged in one-on-one meetings with existing franchisees "I rang the franchisee in (restaurant A) and I rang the franchisee in (restaurant B) and I asked to go and see them" (ER11), "one of the things that helped me ... was ... introductions (to franchisees) to tell their story warts and all" (ER9). The extent of information search engaged in by ERFs relating to the business status of existing franchisees often went far beyond what was proffered at these meetings. For example, the information search behaviors of ER10 even extended to staking out the restaurants of four prominent franchisees to see how busy they were. ER10 then followed these franchisees to observe the size and location of their homes and the type of vehicle they drove to draw notional conclusions about the franchisees' viability and success. Perceiving a subjective knowledge deficiency, all ERFs took the time to engage in on-the-job-evaluations as part of their information search efforts. This involved being 'thrown in at the deep-end' and working unpaid in a franchise for a weekend. For some this on-the-job-evaluation proved critical in providing first-hand knowledge regarding both the nature of the industry and the franchise opportunity "it was pretty helpful (the on-the-job-evaluation)" (ER9).

In contrast, negligible information search was engaged in by the IRFs who instead relied almost totally on their own subjective knowledge regarding the franchise purchase decision. For example, one IRF who had been an employee of the franchisor for 17 years prior to becoming a franchisee, acknowledged relying heavily on their subjective knowledge in "being able to piece together all the different bits (of information) that made sense" (IR4) when making their franchise purchase decision. Likewise, another IRF with 14 years prior employee service chose to almost totally rely on their accumulated subjective knowledge and "did not talk to anyone else" (IR6). Two IRFs (IR5 and IR2) did use a trusted existing franchisee as a sounding board, however the advice was limited to providing mere encouraging feedback "you have just got to do this, trust yourself, you will be fine" (IR5); "you can't go wrong, mate this is it" (IR2), rather than the more rigorous information search behaviors undertaken by ERFs who all spoke extensively to several existing franchisees. Overall, IRFs considered far fewer options than ERFs. Unlike ERFs, IRFs did not actively engage in information search behaviors related to alternative business options and gave little consideration to options other than a franchise within their employer's chain. Indeed, while some IRFs had given no thought to any alternate business routes, others merely had vague contingencies that would only be explored if a franchise offer never eventuated. For example, after more than 20 years of employee service with their franchisor IR4 was prepared to wait for a franchise opportunity within the chain but not wait forever "I did not want to keep doing my corporate role forever ... if I did not get the (franchise) offer then I may have gone down the supermarket route". Similarly, another IRF (IR2) who had been patiently waiting for a franchise offer stated "about 10 years into my career... I thought maybe I would buy a newsagency" but took it no further and never actively pursued the option. Thus, for IRFs these other alternatives were viewed as inferior choices and seen as possible fallback options which would only be actively investigated should a franchise opportunity with their employer not eventuate. Consequently, IRFs engaged in negligible information search efforts in investigating alternative business options. 
The disparity in the starting points of the purchase acquisition process between the ERFs and IRFs cannot be overstated. For the majority of IRFs the franchisor had been their lifelong employer, thus providing them with a vast reservoir of subjective knowledge. These IRFs had often started as young employees and then taken an average of 12.7 years to progress up the ranks of management (see Table 1) before purchasing a franchise. Conversely, most ERFs acknowledged their limited subjective knowledge of the franchisor and its franchise opportunity, thus they engaged in extensive information search to mitigate this deficiency. While two ERFs (ER13 and ER14) had worked for a supplier to the franchisor and thus had some pre-existing knowledge base, many ERFs only prior exposure to the franchisor had merely been as customers and sometimes not even that. In acknowledging their extremely limited subjective knowledge ERF (ER9) observed "I don't think I had even been into a restaurant (of the franchisor)". While ERF (ER11) stated "to be honest, we weren't major frequenters of (the franchisors' restaurants)". Overall, it was concluded that the far greater subjective knowledge possessed by IRFs in comparison to ERFs was instrumental in explaining the negligible information search expended by IRFs.

The two cohorts, ERFs and IRFs held vastly differing perceptions of the risk involved in the franchise purchase decision. Indeed, a strong motive for the significant effort expended on information search by ERFs seemed to be the attenuation of their considerable perception of risk. For example, one ERF (ER10) described themself as being "nervous" and "very conscious of the fact that it was a big gamble". Another ERF (ER11) stated "the risk was always there ... significant for me was that we owned our house. The thing that we said was non-negotiable was that house, so that my spouse would always have a house if I lost everything". ER9, who describing themself as having accrued some capital and being "pretty keen to protect that" also commented that they were "willing to take a risk but it wanted to be a pretty well calculated risk". In contrast, IRFs perceived almost no risk "you know I do not think I thought of any risks at all" (IR3); "I do not think I ever thought it was risky" (IR4); "I did not think much about risks" (IR7); "it was an almost risk-free scenario, the thought of failing didn't really enter my mind ... I had so much faith" (IR6). Perhaps the last word on IRFs' perception of risk goes to IR1 who stated they "could give me a restaurant in a tin shed in the middle of the Nullarbor Plain (a remote Australian desert region) ... and I'd take it". This finding may be partly due to ERFs using more of their own financial capital to purchase their franchises compared to IRFs, with franchisors out of expediency often needing to partly finance IRFs into the system (Bradach 1997). Consequently, the lesser risk assessment by IRFs may have partly been because they had less capital to risk "I have nothing and if this fails will still have nothing ... so I never considered it a risk" (IR1).

A summary of the results the for the purchasing a franchise ERFs versus IRFs can be seen in Table 2.

Table 2. Purchasing a franchise comparison of results-ERFs vs. IRFs (derived from this research).

\begin{tabular}{|c|c|c|}
\hline & Externally Recruited Franchisees & Internally Recruited Franchisees \\
\hline Unmet Need & To Own Their Own Business & To Be Their Own Boss \\
\hline Nature of decision & $\begin{array}{l}\text { Business acquisition } \\
\text { ERFs were on a quest to own their own business. }\end{array}$ & $\begin{array}{l}\text { Career pathway } \\
\text { IRFs made a career choice between continuing to } \\
\text { progress up the corporate ladder with their } \\
\text { franchisor employer or becoming a franchisee, still } \\
\text { with this same franchisor. }\end{array}$ \\
\hline $\begin{array}{l}\text { Subjective } \\
\text { knowledge }\end{array}$ & $\begin{array}{c}\text { Negligible } \\
\text { ERFs had little pre-existing knowledge of the } \\
\text { focal franchise. } \\
\text { Most ERFs had only been customers of the focal } \\
\text { franchise [two had also worked for a supplier]. } \\
\text { One ERF had never previously been in a restaurant } \\
\text { of the franchisor. }\end{array}$ & $\begin{array}{l}\text { Significant } \\
\text { IRFs had vast pre-existing knowledge of the focal } \\
\text { franchise accumulated during an average of } \\
12 \text { years employment with the franchisor. } \\
\text { For most IRFs the focal franchisor had been their } \\
\text { lifelong employer to that point. } \\
\text { All IRFs had been successful restaurant managers } \\
\text { and thus had extensive knowledge of the focal } \\
\text { franchisor's operations. }\end{array}$ \\
\hline
\end{tabular}


Table 2. Cont.

\begin{tabular}{|c|c|c|}
\hline & Externally Recruited Franchisees & Internally Recruited Franchisees \\
\hline Unmet Need & To Own Their Own Business & To Be Their Own Boss \\
\hline Perceived risk & $\begin{array}{l}\text { Significant } \\
\text { ERFs were very conscious of risks in a } \\
\text { franchise purchase. } \\
\text { They described the franchise purchase as } \\
\text { representing a calculated risk. } \\
\text { ERFs expressed their desire to protect assets } \\
\text { and capital. }\end{array}$ & $\begin{array}{l}\text { Negligible } \\
\text { IRFs were not conscious that the franchise } \\
\text { acquisition represented a risk. } \\
\text { They considered that the purchase of a franchise in } \\
\text { the focal franchisor was almost risk-free. } \\
\text { IRFs had few assets to protect. }\end{array}$ \\
\hline $\begin{array}{c}\text { Information search } \\
\text { behaviors }\end{array}$ & $\begin{array}{c}\text { Significant } \\
\text { ERFs engaged in numerous information search } \\
\text { behaviors including but not limited to: Seeking } \\
\text { information related to specific criteria about } \\
\text { various franchises and businesses, not just the } \\
\text { focal franchise. } \\
\text { Engaging with business brokers about } \\
\text { business opportunities. } \\
\text { Reading articles and books about the } \\
\text { focal franchisor. } \\
\text { Conducting one-on-one meetings with numerous } \\
\text { existing franchisees of the focal franchisor. } \\
\text { Engaging in trial on-the-job-evaluations by } \\
\text { working in a franchise for a weekend. }\end{array}$ & $\begin{array}{l}\text { Negligible } \\
\text { IRFs engaged in almost no information } \\
\text { search behaviors. } \\
\text { They did not actively pursue alternative franchises } \\
\text { or business opportunities beyond the focal } \\
\text { franchisor with whom they had been employed. } \\
\text { Rather than consulting widely, IRFs tended to rely } \\
\text { on their own accumulated subjective knowledge of } \\
\text { the focal franchisor. }\end{array}$ \\
\hline
\end{tabular}

\section{Discussion}

Given the financial gravity and long-lasting nature of consumer strategic purchase decisions prior research has taken the position that such decisions are complex, involving extensive problem solving, and requiring significant information search. This did prove to be the case for ERFs who engaging in extensive decision making involving significant information search when purchasing their franchises. However, this was not the case for IRFs who engaged in very limited decision-making that was more akin to habitual decision making. While IRFs had not previously purchased a franchise, nevertheless their years of franchisor employment provided the prolonged experience and "familiarity with the attributes, benefits and the perceived value of the product" (Erasmus et al. 2014, p. 295) that are the usual prerequisites for habitual decision-making. Further evidence for the habitual decision-making characterization of IRFs franchise purchasing behavior was that they were devoid of perceived risk and thus engaged in negligible information search. In light of the notable contrasts shown in Table 2, the Dual Pathway Model in Figure 1 uses the impact of subjective knowledge and perceived risk on information search to resolve the large disparity in information search behaviors exhibited by ERFs versus IRFs in this research. In essence it frames the much higher subjective knowledge of IRFs when compared to ERFs as the underlying explanation for the large differential in the information search behaviors of ERFs when compared to IRFs. IRFs "long preexisting relationship built a foundation of trust" (Bradach 1997, p. 292) in their franchise systems and conferred heightened levels of subjective knowledge surrounding the acquisition of a franchise in that same system. Indeed, as represented in pathway A (see Figure 1) IRFs elevated subjective knowledge directly reduced their motivation to engage in extensive information search as they perceived they already possessed superior knowledge levels. Further, as evidenced in many of the IRFs' quotes pertaining to lack of consideration of risks, their high level of subjective knowledge greatly mitigated their level of perceived risk, which further suppressed their information search behaviors. This is shown in pathways B and C. Pathway $A$ also serves to explain ERFs far more significant information search, as comparatively they possessed little if any subjective knowledge, and thus were motivated to search for more information to fill this knowledge void. This lack of subjective knowledge by ERFs 
also served to elevate their perceived risk (pathway $B$ ) which in turn further enhanced their motivations for information search (pathway $C$ ). Consequently, as represented in the Dual Pathway Model (see Figure 1) the findings of this research suggest that in the context of the consumer strategic purchase decision to buy a franchise, perceived risk acts as a moderating factor that affects the strength of the relationship between subjective knowledge and information search. Significantly, this Figure 1 model differs markedly from Koklic (2011) investigation of similar constructs in the purchase of a prefabricated home where subjective knowledge had a positive relationship with information search and perceived risk did not have a significant impact on the extent of information search behavior.

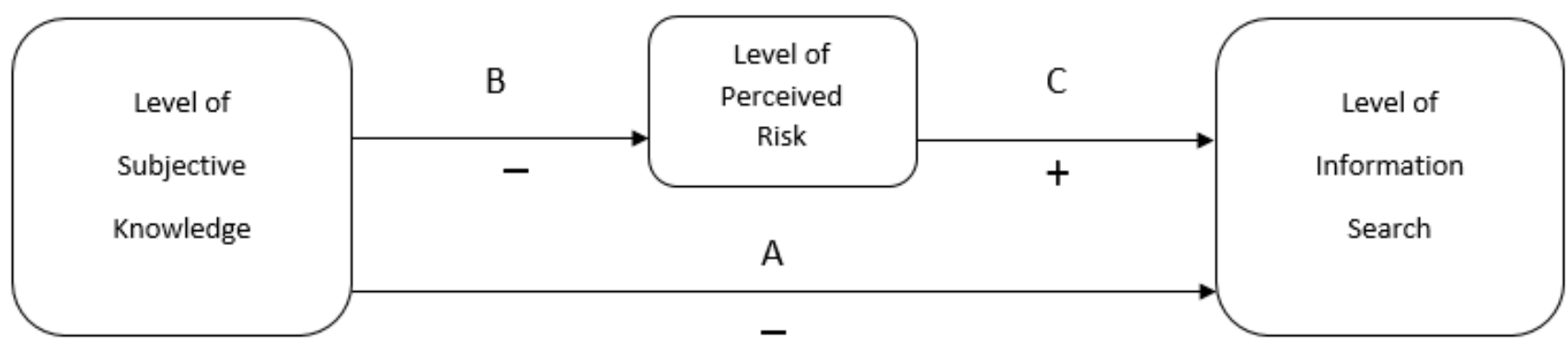

Figure 1. Dual Pathway Model: showing the relationship between subjective knowledge, perceived risk and information search in the purchasing of a franchise (derived from this research).

\subsection{Managerial and Practical Implications}

An ongoing supply of new franchisees remains critical for franchisors' efforts to develop local markets. Thus, given the persistent franchisee shortage, this exploratory research into franchise acquisition processes provides useful insights for franchisors seeking to make their franchisee recruitment efforts more effective. Indeed, better understanding the different franchise buyer decision processes adopted by ERFs and IRFs could lead to more segmented and targeted recruitment efforts by franchisors. A franchise organization that is cognizant of the subjective knowledge deficit of ERFs can then better satiate the information search and risk attenuation needs of ERFs thus leading to a greater proportion of potential ERFs deciding to complete the decision process and purchase a franchise. This research would suggest that actions such as enabling potential ERFs to have interviews with existing franchisees and engaging in trial activities such as on-the-job evaluations may play a significant role in positively assisting ERFs through the franchise purchase process. Likewise, potential IRFs may benefit from undertaking a more extensive franchise purchase decision process. It could be argued that the IRFs in this research suffered from a form of knowledge inflation where they conflated the significant knowledge they possessed about franchises within the single incumbent franchise system where they were employed with broader objective knowledge about the multitude of alternative franchises and business opportunities potentially available in the marketplace. Consequently, the due diligence of their franchise purchase was somewhat compromised by them never investigating these alternative franchises and business opportunities. Indeed, these uninvestigated alternative opportunities represent unknown unknowns for IRFs and suggest a large potential gap between their perceived knowledge and their objective knowledge of the franchise opportunities available in the marketplace. Potential IRFs should adopt a far more rigorous franchise acquisition process not dissimilar to that exhibited by ERFs, involving greater due diligence conducted on a much larger considered set of franchise organizations. In particular, IRFs could benefit by engaging in greater information search and being less myopic by considering business options beyond their incumbent franchise chain. 


\subsection{Theoretical Implications, Future Research Directions and Limitations}

While this work extends consumer strategic purchase decisions to the include the purchase of a franchise, the consumer strategic purchase literature needs to be expanded to address other important products with predominantly intangible characteristics including those designated as once-in-a-lifetime products such as schooling, university, weddings, honeymoons, emigration, and retirement (Yang et al. 2020). Research into the extent to which perceived risk acts as a moderating factor between subjective knowledge and information search in purchase situations other than franchises also needs further investigation. As the franchising literature has only one prior study with IRFs as a focus this work begins to address the apparent gap between the widespread industry practice of recruiting franchisees internally and IRFs absence in the literature. Indeed, future research could also explore how the consumer decision process changes for the subsequent franchise purchases of IRFs and ERFs who become multi-unit franchisees. Do the constructs of subjective knowledge, perceived risk and information search differ from those involved in their initial franchise purchase?

This research has limitations. As this study is exploratory, further descriptive research is needed to verify its findings with respect to the summary in Table 2 and the model in Figure 1. To limit extraneous variables and facilitate this study's focus on the contrast between ERFs and IRFs all participants were Australian franchisees from the same restaurant chain. Thus, future research across industries and geographies may serve to further validate the extent of the generalizability of the findings of this study. The sample was purposively selected, thus limiting the findings across populations (Teddlie and Yu 2007), however they may apply in similar situations.

\section{Conclusions}

For many organizations, franchising is their key method of facilitating growth and local market development. Success in franchising relies on maintaining access to an ongoing pool of suitable franchisees however, for many franchisors a lack of franchisees has been a key growth constraint. This research provides insights into the relationship between subjective knowledge, perceived risk and information search behaviors undertaken by two distinct categories of franchisees, ERFs and IRFs, when purchasing their franchises. Franchisors can use these insights to be better placed to source new franchisees, conclude sales of new franchises and thereby build their local market development capacity. Contrary to prior research suggesting that such strategic purchases require extensive decisionmaking, this exploration found a divergence of approaches between ERFs and IRFS when purchasing their franchises. While an extensive decision-making process was inherent in the franchise purchase decision processes of ERFs this was not the case for IRFs. IRFs engaged in limited, almost habitual decision-making processes when purchasing their franchises. Finally, the Dual Pathway Model (see Figure 1) was developed to show the relationship between subjective knowledge, perceived risk and information search in the purchasing of a franchise and reconcile the findings.

Author Contributions: Conceptualization, P.B., C.L. and M.M.R.; methodology, P.B., C.L., M.M.R. and M.M.; formal analysis P.B., C.L. and M.M.R.; investigation, P.B.; writing-original draft preparation, P.B.; writing — review and editing, P.B., C.L., M.M.R. and M.M.; supervision, C.L. and M.M.R.; All authors have read and agreed to the published version of the manuscript.

Funding: No funding was provided for this research.

Conflicts of Interest: No financial interest or benefit has arisen from the application of this research. 


\section{References}

Alchian, Armen A., and Harold Demsetz. 1972. Production, Information Costs, and Economic Organization. The American Economic Review 62: 777-95.

Alon, Ilan. 2001. The use of franchising by U.S.-based retailers. Journal of Small Business Management 39: 111-22. [CrossRef]

Ashman, Rachel, Michael Solomon, and Julia Wolny. 2015. An old model for a new age: Consumer decision making in participatory digital culture. Journal of Customer Behavior 14: 127-46. [CrossRef]

Attride-Stirling, Jennifer. 2001. Thematic networks: An analytic tool for qualitative research. Qualitative Research 1: 385-405. [CrossRef]

Atwell, Courtenay. 2015. The franchisee as a consumer: Determining the optimal duration of pre-contractual disclosure. Journal of Consumer Policy 38: 457-89. [CrossRef]

Balsarini, Peter, Claire Lambert, and Marie M. Ryan. 2020. Why franchisors recruit franchisees from the ranks of their employees. Journal of Strategic Marketing, 1-21. [CrossRef]

Bazerman, Max H. 2001. Consumer research for consumers. Journal of Consumer Research 27: 499-504. [CrossRef]

Bender, John. 2015. Barking up the wrong tree: The NRLB's joint-employer standard and the case for preserving the formalities of business format franchising. Franchise Law Journal 35: 209-35.

Boulay, Jacques, Barbara Caemmerer, Heiner Evanschitzky, and Krista Duniach. 2016. Growth, uniformity, local responsiveness, and system-Wide adaptation in multiunit franchising. Journal of Small Business Management 54: 1193-205. [CrossRef]

Bradach, Jeffrey. 1995. Chains within chains: The role of multi-unit franchisees. Journal of Marketing Channels 4: 65-81. [CrossRef]

Bradach, Jeffrey. 1997. Using the plural form in the management of restaurant chains. Administrative Science Quarterly 42: 276-76. [CrossRef]

Braun, Virginia, and Victoria Clarke. 2006. Using thematic analysis in psychology. Qualitative Research in Psychology 3: 77-101. [CrossRef]

Braun, Virginia, and Victoria Clarke. 2019. Reflecting on reflexive thematic analysis. Qualitative Research in Sport, Exercise and Health 11: 589-97. [CrossRef]

Brucks, Merrie. 1985. The effects of product class knowledge on information search behavior. Journal of Consumer Research 12: 1-16. [CrossRef]

Buchan, Jenny. 2009. Consumer protection for franchisees of failed franchisors: Is there a need for statutory intervention? Queensland University of Technology Law and Justice Journal 9: 232-50. [CrossRef]

Buchan, Jenny. 2013. Franchisees as Consumers: Benchmarks, Perspectives and Consequences. New York: Springer.

Bürkle, Thomas, and Thorsten Posselt. 2008. Franchising as a plural system: A risk-based explanation. Journal of Retailing 84: 39-47. [CrossRef]

Chaudhuri, Arjun. 2002. A study of emotion and reason in products and services. Journal of Consumer Behavior 1: 267-79. [CrossRef]

Conchar, Margy P., George M. Zinkhan, Caraa Peters, and Sergio Olavarrieta. 2004. An integrated framework for the conceptualization of consumers' perceived-risk processing. Journal of the Academy of Marketing Science 32: 418-36. [CrossRef]

Corbin, Juliet. 2017. Grounded theory. Journal of Positive Psychology 12: 301-2. [CrossRef]

Creswell, John. 2014. Research Design, 4th ed. Thousand Oaks: Sage.

Croonen, Evelien, Maryse Brand, and Eelko Huizingh. 2016. To be entrepreneurial, or not to be entrepreneurial? Explaining differences in franchisee entrepreneurial behavior within a franchise system. International Entrepreneurship and Management Journal 12: 531-53. [CrossRef]

Dada, Olufunmilola, Anna Watson, and David Kirby. 2015. Entrepreneurial tendencies in franchising: Evidence from the UK. Journal of Small Business and Enterprise Development 22: 82-98. [CrossRef]

Dant, Rajiv, Marko Grunhagen, and Josef Windsperger. 2011. Franchising research frontiers for the twenty-first century. Journal of Retailing 87: 253-68. [CrossRef]

Dant, Rajiv, Scott Weaven, and Brent Baker. 2013. Influence of personality traits on perceived relationship quality within a franchiseefranchisor context. European Journal of Marketing 47: 279-302. [CrossRef]

Darley, William K., Charles Blankson, and Denise J. Luethge. 2010. Toward an integrated framework for online consumer behavior and decision making process: A review. Psychology \& Marketing 27: 94-116.

Darr, Eric, Linda Argote, and Dennis Epple. 1995. The acquisition, transfer, and depreciation of knowledge in service organizations: Productivity in franchises. Management Science 41: 1750-62. [CrossRef]

Denzin, Norman, and Yvonna Lincoln. 2005. The Sage Handbook of Qualitative Research, 3rd ed. Thousand Oaks: Sage Publications.

Dowling, Grahame R., and Richard Staelin. 1994. A model of perceived risk and intended risk-handling activity. Journal of Consumer Research 21: 119-34. [CrossRef]

Eisenhardt, Kathleen. 1989. Agency theory: An assessment and review. Academy of Management Review 14: 57-74. [CrossRef]

Engel, James, David Kollat, and Roger Blackwell. 1978. Consumer Behavior, 3rd ed. Hinsdale: Dryden.

Erasmus, Aletta C., Elizabeth Boshoff, and Gabriel G. Rousseau. 2001. Consumer decision making models within the discipline of consumer science: A critical approach. Journal of Family Ecology and Consumer Sciences 29: 82-90. [CrossRef]

Erasmus, Aletta C., Sune Donoghue, and Thomas Dobbelstein. 2014. Consumers' perception of the complexity of selected household purchase decisions. Journal of Retailing and Consumer Services 21: 293-305. [CrossRef] 
Frandata. 2021. Economic Outlook for Franchising. Washington, DC: International Franchise Association, Available online: https: //www.franchise.org/sites/default/files/2021-02/Economic\%20Outlook\%202021_web2.pdf (accessed on 10 March 2021).

Frazer, Heather. 2004. Doing narrative research: Analysing personal stories line by line. Qualitative Social Work 3: 179-201. [CrossRef]

Frazer, Lorelle, Scott Weaven, and Kelli Bodey. 2010. Franchising Australia 2010. Brisbane: Asia Pacific Centre for Franchising Excellence, Griffith University.

Frazer, Lorelle, Scott Weaven, and Kelli Bodey. 2012. Franchising Australia 2012. Brisbane: Asia Pacific Centre for Franchising Excellence, Griffith University.

Frazer, Lorelle, Scott Weaven, and Anthony Grace. 2014. Franchising Australia 2014. Brisbane: Asia Pacific Centre for Franchising Excellence, Griffith University.

Frazer, Lorelle, Jenny Buchan, Scott Weaven, Binh Tran-Nam, and Anthony Grace. 2016a. The Effectiveness of Undertaking Due Diligence Prior to Starting up or Purchasing a Small Business or Franchise. Final Report. Sydney: Asia Pacific Centre for Franchising Excellence, Griffith University, Gold Coast, Australia and the University of NSW, Available online: http:/ / unsworks.unsw.edu.au/fapi/ datastream/unsworks:40047/binf4a7a68f-4e3f-4cdc-95c4-091c65ec4591?view=true (accessed on 15 July 2021).

Frazer, Lorlele, Scott Weaven, Anthony Grace, and Selva Selvanathan. 2016b. Franchising Australia 2016. Brisbane: Asia Pacific Centre for Franchising Excellence, Griffith University.

Gibler, Karen, and Susan Nelson. 2003. Consumer behavior applications to real estate education. Journal of Real Estate Practice and Education 6: 63-83. [CrossRef]

Grace, Debra, and Scott Weaven. 2011. An empirical analysis of franchisee value-in-use, investment risk and relational satisfaction. Journal of Retailing 87: 366-80. [CrossRef]

Grace, Anthony, Lorelle Frazer, Scott Weaven, and Rajiv Dant. 2016. Building franchisee trust in their franchisor: Insights from the franchise sector. Qualitative Market Research 19: 65-83. [CrossRef]

Gronhaug, Kjell, Ingeborg A. Kleppe, and Willy Haukedal. 1987. Observation of a strategic household purchase decision. Psychology $\mathcal{E}$ Marketing 4: 239-53.

Guest, Greg, Arwen Bunce, and Laura Johnson. 2006. How many interviews are enough? An experiment with data saturation and variability. Field Methods 18: 59-82. [CrossRef]

Hadar, Liat, Sanjay Sood, and Craig R. Fox. 2013. Subjective knowledge in consumer financial decisions. Journal of Marketing Research 50: 303-16. [CrossRef]

Hing, Nerilee. 1995. Franchisee satisfaction: Contributors and consequences. Journal of Small Business Management 33: 12-25.

Karimi, Sahar, Nadia Papamichail, and Christopher P. Holland. 2015. The effect of prior knowledge and decision-making style on the online purchase decision-making process: A typology of consumer shopping behaviour. Decision Support Systems 77: 137-47. [CrossRef]

Karimi, Sahar, Christopher P. Holland, and Nadia Papamichail. 2018. The impact of consumer archetypes on online purchase decision-making processes and outcomes: A behavioural process perspective. Journal of Business Research 91: 71-82. [CrossRef]

Kaufmann, Patrick J. 1999. Franchising and the choice of self-employment. Journal of Business Venturing 14: 345-62. [CrossRef]

Kaufmann, Patrick J., and Sevgin Eroglu. 1999. Standardization and adaptation in business format franchising. Journal of Business Venturing 14: 69-85. [CrossRef]

King, Nigel, and Joanna Brooks. 2018. Thematic analysis in organisational research. In The SAGE Handbook of Qualitative Business and Management Research Methods. Edited by Catherine Cassell, Ann L. Cunliffe and Gina Grandy. London: SAGE Publications Ltd., pp. 219-36. [CrossRef]

Koklic, Mateja K. 2011. The consumer's perceived risk when buying a home: The role of subjective knowledge, perceived benefits of information search behavior. Privredna Kretanjua I Ekonomska Politika 21: 27-50.

Koklic, Mateja K., and Irena Vida. 2011. Consumer strategic decision making and choice process: Prefabricated house purchase. International Journal of Consumer Studies 35: 634-43. [CrossRef]

Kroc, Ray, and Robert Anderson. 1977. Grinding It Out: The Making of McDonald's. Chicago: Contemporary Books, Inc.

Labuschagne, Adri. 2003. Qualitative research-Airy fairy or fundamental? The Qualitative Report 8: 100-3.

Lafontaine, Francine. 1992. Agency theory and franchising: Some empirical results. Rand Journal of Economics 23: 263-83. [CrossRef]

Lafontaine, Francine, and Patrick J. Kaufmann. 1994. The evolution of ownership patterns in franchise systems. Journal of Retailing 70: 97-113. [CrossRef]

Lashley, Conrad, and Alison Morrison. 2000. Franchising Hospitality Services. Oxford: Butterworth/Heinmann.

Lye, Ashley, Wei Shao, Sharyn Rundle-Thiele, and Carolyn Fausnaugh. 2005. Decision waves: Consumer decisions in today's complex world. European Journal of Marketing 39: 216-30. [CrossRef]

MacPhail, Catherine, Nomhle Khoza, Laurie Abler, and Meghna Ranganathan. 2016. Process guidelines for establishing intercoder reliability in qualitative studies. Qualitative Research 16: 198-212. [CrossRef]

Maity, Moutusy, and Mayukh Dass. 2014. Consumer decision making across modern and traditional channels: E-commerce, mcommerce, in-store. Decision Support Systems 61: 34-46. [CrossRef]

Martin, Jillian, Gary Mortimer, and Lynda Andrews. 2015. Re-examining online customer experience to include purchase frequency and perceived risk. Journal of Retailing and Consumer Services 25: 81-95. [CrossRef]

McDonald's. n.d. Our History. Available online: https:// corporate.mcdonalds.com/corpmcd/about-us/history.html (accessed on 10 March 2021). 
McNeal, James U., and Stephen W. McDaniel. 1981. The role of consumer knowledge in the study of consumer behavior. Journal of Marketing Education 3: 37-41. [CrossRef]

Meiseberg, Brinja. 2013. The prevalence and performance impact of synergies in the plural form. Managerial and Decision Economics 34: 140-60. [CrossRef]

Minkler, Alanson. 1992. Why firms franchise: A search cost theory. Journal of Institutional and Theoretical Economics 148: $240-59$.

Nedungadi, Prakash. 1990. Recall and consumer consideration sets: Influencing choice without altering brand evaluations. Journal of Consumer Research 17: 263-76. [CrossRef]

Norton, Seth. 1988a. An empirical look at franchising as an organizational form. The Journal of Business 61: 197-218. [CrossRef]

Norton, Seth. 1988b. Franchising, brand name capital, and the entrepreneurial capacity problem. Strategic Management Journal 9: 105-14. [CrossRef]

Oh, Keunyuong, and Lisa Abraham. 2016. Effect of knowledge on decision making in the context of organic cotton clothing. International Journal of Consumer Studies 40: 66-74. [CrossRef]

Oxenfeldt, Alfred, and Anthony Kelly. 1969. Will successful franchise systems ultimately become wholly-owned chains? Journal of Retailing 44: 69-83.

Oxford Dictionaries. n.d.a. Information. Available online: https:/ / en.oxforddictionaries.com/definition/information (accessed on 29 June 2021).

Oxford Dictionaries. n.d.b. Meaning of Guanxi in English. Available online: https://en.oxforddictionaries.com/definition/guanxi (accessed on 1 May 2021).

Park, C. Whan, and V. Parker Lessig. 1981. Familiarity and its impact on consumer decision biases and heuristics. Journal of Consumer Research 8: 223-31. [CrossRef]

Perryman, Alexa, and James Combs. 2012. Who should own it? An agency-based explanation for multi-outlet ownership and co-location in plural form franchising. Strategic Management Journal 33: 368-86. [CrossRef]

Pillon, Annie. 2019. Secrets of transitioning from employee to franchise ownership. Small Business Trends Magazine. Available online: https:/ / smallbiztrends.com/2019/04/franchise-employee-to-franchise-owner.html (accessed on 15 March 2021).

Punj, Girish. 1987. Research decision making in consumer durable purchases. The Journal of Consumer Marketing 4: 71-82. [CrossRef]

Punj, Girish, and Richard Brookes. 2002. The influence of pre-decisional constraints on information search and consideration set formation in new automobile purchases. International Journal of Research in Marketing 19: 383-400. [CrossRef]

Radecki, Carmen M., and James Jaccard. 1995. Perceptions of knowledge, actual knowledge, and information search behavior. Journal of Experimental Social Psychology 31: 107-37. [CrossRef]

Raju, P. S., Subhash C. Lonial, and W. Glynn Mangold. 1995. Differential effects of subjective knowledge, objective knowledge, and usage experience on decision making: An exploratory investigation. Journal of Consumer Psychology 4: 153-80. [CrossRef]

Rubin, Paul. 1978. The theory of the firm and the structure of the franchise contract. The Journal of Law and Economics 21: 223-33. [CrossRef]

Saunders, Mark, Philip Lewis, and Adrian Thornhill. 2009. Research Methods for Business Students, 5th ed. Harlow: Pearson.

Savolainen, Reijo. 2009. The information needs of prospective homebuyers: An exploratory study of apartment purchases in Finland. International Journal of Consumer Studies 33: 566-71. [CrossRef]

Shocker, Allan D., Moshe Ben-Akiva, Bruno Boccara, and Prakash Nedungadi. 1991. Consideration set influences on consumer decision making and choice: Issues, models, and suggestions. Marketing Letters 2: 181-97. [CrossRef]

Spencer, Elizabeth. 2013. The applicability of unfair contract terms legislation to franchise contracts. University of Western Australia Law Review 37: 156-75.

Srinivasan, Narasimhan, and Brian T. Ratchford. 1991. An empirical test of a model of external search for automobiles. Journal of Consumer Research 18: 233-42. [CrossRef]

Storholm, Gordon, and Eberhard Scheuing. 1994. Ethical implications of business format franchising. Journal of Business Ethics 13: 181-88. [CrossRef]

Stowe, Sarah. 2015. From Head Office Employee to Franchisee: Alex Camplin. Inside Franchise Business Magazine. Available online: https: / / www.franchisebusiness.com.au/from-head-office-employee-to-franchisee-alex-campl/ (accessed on 15 March 2021).

Syed, Rizwan, and Sandrine Syed. 2019. On the Hunt for a Franchisee? Take a Look at Your Own Employees. Smart Company. Available online: https://www.smartcompany.com.au/business-advice/franchising/finding-franchisee-look-own-employees / (accessed on 15 March 2021).

Taylor, Kate. 2015. Why Former Employees Make Great Franchisees. Entrepreneur Magazine. Available online: https://www. entrepreneur.com/article/246686 (accessed on 15 March 2021).

Teddlie, Charles, and Fen Yu. 2007. Mixed methods sampling: A typology with examples. Journal of Mixed Methods Research 1: 77-100. [CrossRef]

Utkarsh. 2017. Individual differences in consumer information search for services: A multiple mediation study. Journal of Retailing and Consumer Services 37: 33-42. [CrossRef]

Utkarsh, Sunanda Sangwan, and Pallavi Agarwal. 2019. Effect of consumer self-confidence on information search and dissemination: Mediating role of subjective knowledge. International Journal of Consumer Studies 43: 46-57. [CrossRef]

Virdi, Preeti, Arti D. Kalro, and Dinesh Sharma. 2020. Online decision aids: The role of decision-making styles and decision-making stages. International Journal of Retail E Distribution Management 48: 555-74. [CrossRef] 
Watson, Anna, Olufunmilola Dada, Marko Grünhagen, and Melody Wollan. 2016. When do franchisors select entrepreneurial franchisees? an organizational identity perspective. Journal of Business Research 69: 5934-45. [CrossRef]

Wei, Pei-Shan, and Hsi-Peng Lu. 2013. An examination of the celebrity endorsements and online customer reviews influence female consumers' shopping behavior. Computers in Human Behavior 29: 193-201. [CrossRef]

Yang, Hsiao-Pei, Dorothy Yen, and John M. T. Balmer. 2020. Higher education: A once-in-a-lifetime purchase. Qualitative Market Research: An International Journal 23: 865-90. [CrossRef]

Yeung, Ruth, Maureen Brookes, and Levent Altinay. 2016. The hospitality franchise purchase decision making process. International Journal of Contemporary Hospitality Management 28: 1009-25. [CrossRef] 